\title{
Public Water Supply and Sanitation Authorities for Strategic Sustainable Domestic Water Management. A Case of Iringa Region In Tanzania
}

\author{
Mesia Lufingo ${ }^{1,2}$ (D) \\ 1 Department of Water and Environmental Science and Engineering, Nelson Mandela African Institution of \\ Science and Technology, Arusha P.O. Box 447, Tanzania; Lufingom@nm-aist.ac.tz or \\ Mesia.ngahala@maji.go.tz; Tel.: +255-755-142-521 \\ 2 Iringa Water Quality Laboratory, Department of Water Quality Services, Ministry of Water, \\ Iringa P.O. Box 570, Tanzania
}

Received: 2 August 2019; Accepted: 14 October 2019; Published: 18 October 2019

check for updates

\begin{abstract}
Water supply is a mandatory service for the majority from respective legal public water utilities, and its sustainability reflects implementations of best management strategies at a local level. The objectives of this study were (i) to assess current approaches used in water quality and quantity management and (ii) propose a sustainable domestic water management strategy. This was achieved through secondary water data trends, on-site water quality assessments, visits of water supply and sanitation authorities, and assessment of their performances. It was observed that water supplied in rural-based authorities was quite different from that supplied in an urban setting as far as quality and quantity are concerned; urban-based supplies are more affordable to users than rural ones. A new strategy on water management is presented for sustainable water supply; it is based on controlling groundwater abstractions and preference of surface water in public water supplies. Rural water supply management must learn several practices realized in urban supplies for the betterment of services for the majority of the users.
\end{abstract}

Keywords: community-owned water supply organization (COWSO); domestic water management strategy; water quality; water quantity; water supply and sanitation authority (WSSA)

\section{Introduction}

Globally, water is considered to be conserved by the hydrological cycle $[1,2]$ and covers $75 \%$ of the planet earth, in which only $2.5 \%$ is freshwater [3]. The freshwater portion under the conservation concept is rather diminishing, i.e., $80 \%$ of wastewater is globally not treated, and only $10 \%$ is treated efficiently [4], due to increased demand through global population growth over time $[5,6]$. Major sectors that are essential for economic growth are agriculture, industries, and domestic water supplies $[7,8]$. Apart from stable ice-locked water and paleo-groundwater, freshwater flows and their interactions within the hydrologic cycle do not guarantee availability at their origin points, i.e., uneven distribution [9,10]; consequently, freshwater becomes scarce [2,11-13] and a common good [14] where businesses intervene [15-17]. While all countries are trying to account for the freshwater sustainability dilemma [18-23], international policies favor virtual water exploitation as all countries are relatively economically interdependent [24-27].

Like other countries, Tanzania is also facing a similar situation [28], where the agricultural sector is the backbone of the country's economy [29-33], supporting 80\% of Tanzanians' occupations and $95 \%$ of food [34-36]. Freshwater use has been given first priority for basic human needs under domestic water supply [37], and the environment receives second priority, but other sectors, 
including agriculture, are periodically given other priorities based on their real-time socioeconomic significance [38]. Even with firsthand prioritization of water for domestic use, many Tanzanians receive limited freshwater due to poor water resource management $[39,40]$. While many water sources used for domestic water supply become insufficient due to poor management, it has been a common practice to seek alternative water sources to supplement the existing ones. This idea threatens the second water priority of the environment over domestic favor, leaving agriculture, together with other sectors, to experience the worst scenario. Many successful water supply projects are utilizing fresh surface water sources over gravity-driven water supply, but when this option is not available in other communities, the pumping of either available ground or surface water sources is preferred. Unfortunately, the cost for supplied, treated, and electrically pumped water is unbearable to low-income individuals residing in rural settings [41].

Water quality is another criterion for freshwater source suitability in domestic use. Currently, groundwater is largely preferred over surface water due to a general perceived good water quality [42,43], regardless of the potential existence of chemical pollutants [44-47]. Since much effort is devoted to fresh surface waters, no attention in Tanzania laws and policies on the promotion and regulation of groundwater use have been effectively emphasized [48]. Thus, it has become a common practice where those who can afford to drill have legal and illegal access to groundwater, irrespective of critical issues, such as compromising aquifer composition and content leading to groundwater pollution, as well as overexploitation that mismatches recharge rates [49]. Since surface and ground waters are greatly interrelated [50], it is meaningless to solely put efforts on surface water source management. Furthermore, it has been evident that groundwater is greatly advocated for agricultural practices [51-54], which makes freshwater vulnerable to pollution and overexploitation, as contrasted from the water resource use priorities by [38].

Rainwater harvesting is a mature technology used for sustaining agricultural activities [55], but due to an increased freshwater crisis, it is currently receiving a lot of credit as a potential alternative and as a management strategy for sustainable water supply [56-58]. However, since it is not available to all places during the entire rainy season and due to the fact that it is vulnerable to pollution [59], it cannot reliably and exclusively be preferred in all areas with freshwater demands. Hence different management approaches that can supplement it and other sectors in a sustainable manner must be explored and implemented accordingly.

This paper explores public water supply and sanitation authorities as a management strategy for freshwater resources. The management concept is clearly addressed in terms of water quality and quantity aspects using the Iringa region in Tanzania as a case study. It is anticipated that, when this option is taken into consideration by relevant regulatory bodies under respective policies and regulations, it will be a potential preference in the toolbox towards better management of freshwater resources for integrating sectors and enable them to operate sustainably.

\section{Materials and Methods}

\subsection{Study Area}

This section provides an overview description of the Iringa region (Figure 1), which is located between $7.77^{\circ} \mathrm{S}$ and $35.69^{\circ} \mathrm{E}$ of Tanzania's southern highland zones. Dodoma and Singida regions are surrounding the northern part, Njombe (formerly being part of the Iringa region) in the south, Morogoro in the east, and Mbeya to the west. Iringa, with an area of about $36,000 \mathrm{~km}^{2}$ has four administrative districts, i.e., Iringa Municipal, Iringa Rural, Mufindi, and Kilolo, with a total population of about 151,000. Water demands in the region are extremely high due to agricultural activities being dominant and accounting for $85 \%$ of the region's gross domestic product (GDP). Water scarcity in this region with many water resources has attracted many research studies and water supply project developments. The availability of newly developed water supply projects under several funders was the reason for its case study suitability. Furthermore, most localized water projects (at community 
level) with at least chlorination treatment practices are available in the region and account for its exclusive study area suitability that reflects future implications on clean and safe water provision for all. This reflected an operational and functional performance reality that relates to the potential opportunities for water management strategies in Tanzania.

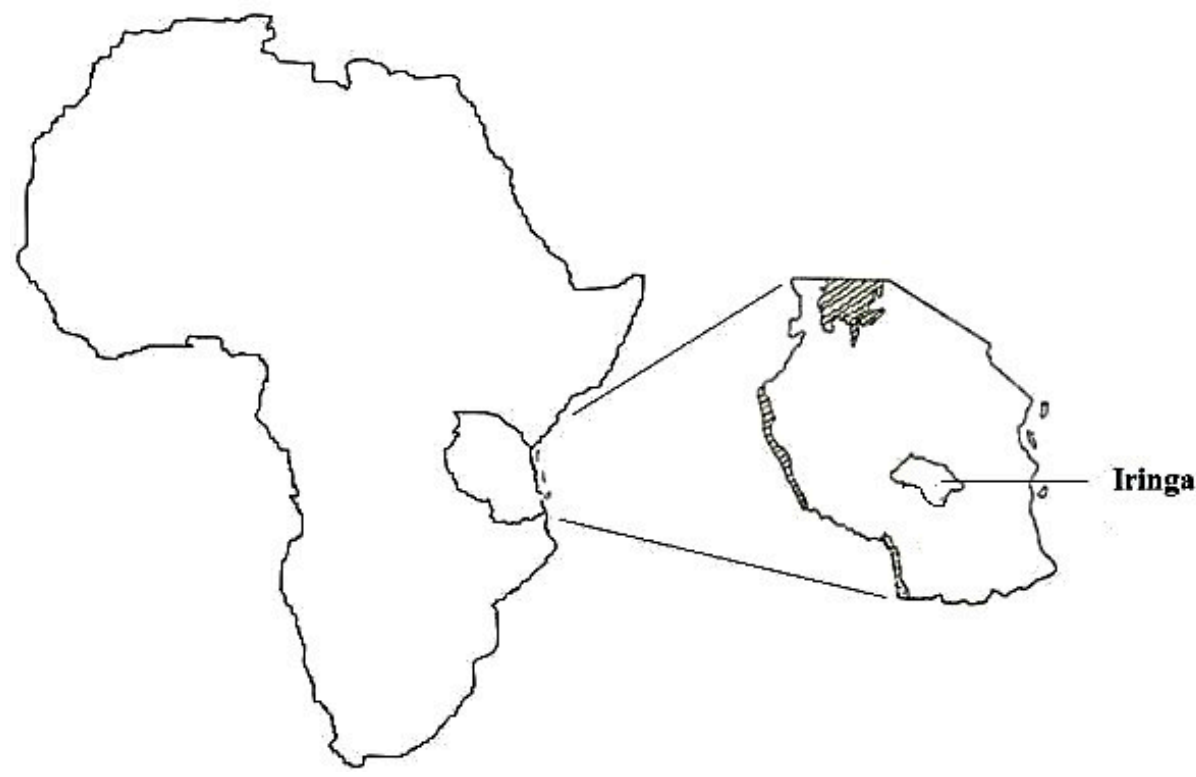

Figure 1. A Sketch map showing the Locality of the Iringa region (Modified from [60]).

\subsection{Water Quality}

\subsubsection{Water Quality Assessment-Heavy Metals}

Sixteen (16) heavy metals i.e., aluminium, arsenic, barium, cadmium, chromium, cobalt, copper, iron, lead, manganese, mercury, molybdenum, nickel, selenium, silver, and zinc were analyzed by an inductively coupled plasma (ICP) in raw and treated water samples from Little Ruaha River, which is the major source of public water supply in Iringa Municipality. Other samples analyzed were from Kibwabwa Borehole and Kitwiru spring, which altogether supplement the Iringa Urban Water Supply and Sanitation Authority (IRUWASA) supply. All water quality samples were collected, preserved, and analyzed according to the standard method for the examination of water and wastewater [61].

\subsubsection{Water Quality Trends}

Secondary data from Iringa Water Quality Laboratory (IWQL) database were used to study the long-term (2015 to 2018) behavior of surface (rivers, streams, dams, ponds, wetlands, and wastewaters) and ground (deep wells, shallow wells, and springs) water qualities across the Iringa region. These data were mostly based on monthly and quarterly water quality monitoring programmes, although semi-annual and annual monitoring programmes were also considered. All data within the study period were entered in an excel spreadsheet and manipulated for comments using "IF" function to provide the complying and noncomplying status of all considered water sources. Unlike complying samples, where only the "complies" status was provided by the function, noncomplying comments were further identified by a respective out of range parameter. Noncomplying physico-chemical and microbial parameters were used for trend analysis, whereas parameters that consistently complied with available national guidelines [62] for the trend period were not considered. Seasonal variations (dry and wet) were also taken into consideration for the entire trend. Trend analysis was realized from yearly plots of nonqualifying water quality parameters for the considered period. 


\subsubsection{Water Quality Perception}

During site visits, ten (10) people from the management and technical part of the Water Supply and Sanitation Authority (WSSA) staff, including public kiosk operators, as well as twenty (20) people from the majority of water users were formally requested to provide their water quality perception based on daily water use experience from each of the eleven (11) visited WSSAs. The following questionnaires were restricted to three hundred and thirty (330) participants: (i) What do you consider as an indicator for quality water? (ii) Is it worth to treat polluted water for domestic uses? (iii) How do you feel about using chlorinated water? Comments were noted concerning available treatment practices and seasonal variation issues. Data were analyzed using an excel spreadsheet with the help of a word analyzer programme during coding of observed responses for statistical treatment.

\subsection{Water Quantity}

\section{Assessment of WSSA Current Practices}

Study area visits were implemented over 11 WSSAs (one municipal/urban, three small town/district, and seven rural-based community owned water supply organizations-COWSO), where information regarding population served, treatment practices, number of meters/private connections, water use tariffs, and payment modalities (e.g., flat rate or as per quantity consumed) were captured in relation to water management strategies.

\section{Results and Discussion}

\subsection{Limitation of the Study}

Several observations were noted to have a potential influence on this study; they included using secondary water quality data from a competent laboratory. Here, qualification and disqualification of water samples were based on East African potable water standards, which could be different from other country's guidelines. Furthermore, the case study is characterized by many surface water sources, whereas other regions with drought dominance may lack representations, especially in the water quality section, which can be characterized in a different manner than the one presented herein. The heavy metal assessment was done only at the urban-based water supply authority due to analytical cost implications; rural-based supplies were not accomplished in this case and could have established another compelling relationship. Rural based supplies selected in this study were based on recently developed projects ( $\leq 1$ year), which could have presented unique information compared to old projects that still operate at the same level and locality; their selection was also a function of availability of a treatment practice, i.e., chlorination.

\subsection{Quality Aspect}

\subsubsection{Water Testing}

\section{Privately Owned Water Sources}

The concept behind WSSA as a water resource management strategy extends itself to quality issues that strictly define the suitability of any secured freshwater source for domestic use. Currently, all WSSAs in Tanzania are legally established and recognized by [63] as an amendment of [64], which continues to address internal and external requirements on regular water quality monitoring. Thus, water supplied by these entities is of known quality, which is accountable for public health protection. In urban settings, water supplies are perceived to be relatively expensive compared to rural areas, which is due to multi-step treatment expenses of polluted surface water sources from rivers and streams. Individuals and institutions that are financially sound tend to opt for user permits over deep groundwater sources as they are economically feasible to operate once established. Furthermore, 
their quality is observed to be superior when compared to treated surface water supplies, which are believed to contain residual treatment chemicals that could affect people's health. The majorities with limited financial capacities are also interested in shallow groundwater sources; fortunately, [65] has a free of permit room for individuals utilizing groundwater within a few meters deep. Individuals and institutions located far from WSSA networks usually secure their permitted water from nearby running surface waters, and/or groundwater abstractions. However, almost all of these privately owned water sources are not tested and or monitored for water quality status in their entire operational periods; in rare cases, a water test is realized only when it is a regulatory requirement that is accompanied by an inspection from a compliance body.

What is urged here is that water quality tests are too technical and very expensive among privately owned water users. Furthermore, Tanzania's government has only sixteen (16) regional water laboratories for this task; thus, it becomes even more expensive to arrange the necessary logistics for remote and on-site testing, including transport and technical staff per diem [66]. The following are technical suggestions, based on water quality assessment experience, towards alleviating unnecessary setbacks, and thus, facilitating convenient and smooth water testing means for all privately owned water sources:

Water samplings are greatly emphasized at sources or intakes rather than existing domestic points. It takes a long time to visit remote surface water source intakes for the same water available near residential or easily accessible areas. Besides, it presents increased cost (e.g., per diem) to the technical staff during monitoring sessions, which private water source owners find higher than the analysis cost. Thus, samples shall only be taken at point of use, and for a new source, the closest downstream point shall be preferred as its quality would be a representative of the source intake to a large extent, unless a point source of pollution is identified to interfere.

-Water sampling and preservation prior to laboratory conveyance for microbial assessment shall be taken by private water source owners using guidelines presented by [67]. Glass bottles that require an autoclave for sterilization can be replaced by locally sold bottled water, as their cleanliness is assured by good manufacturing practices and regular factory and market monitoring by legal Tanzania quality regulatory bodies.

- Water quality testing laboratories should be simpler and less costly through the concept presented by [68], where electric conductivity (EC) shall be the basis of omitting unnecessary chemical parameters that could only increase analytical expenses, which is a burden and one of the critical reasons as to why the majority do not prefer water testing.

\section{Publicly Owned Water Sources}

While WSSAs are strictly obliged to test and monitor their water quality supplies, rural-based WSSAs with limited financial and analytical technical capabilities are experiencing a similar scenario comparable to that of privately owned water sources. Thus, solutions presented for privately owned water sources on enhancing regular water quality testing following proposed cost-effective sampling in 3.2.1.1 above can be adopted here. Unlike privately owned water sources, WSSA legal water quality compliances are required for reporting to the respective regulatory authority, i.e., The Energy and Water Utilities Regulatory Authority (EWURA). The current paradigm of respective WSSAs to directly report on EWURA is questioned based on regular EWURA monitoring programs, the results of which are quite different from regularly reported trends by most WSSAs [69]. There are possible incidences where results are directly entered over online platforms, even without realizing any water quality monitoring programme. In order to avoid this, analytical results shall be directly entered by a respective water quality laboratory that executed the analytical task, and the same should be declared if not done. Furthermore, since compliance is an issue here, WSSAs implementing the proposed privately owned water sources sampling option shall be accompanied by another legally accountable and nearby available qualified staff (e.g., regional, district, and/or town environmental/water engineers, scientists, and technicians). 
Currently, most WSSAs are implementing chlorination practices to publicly supplied water as a safeguard step against endemic diseases following recent cholera outbreaks throughout the country $[70,71]$. However, majority citizens utilizing such treated water are complaining about this new chemical that has been added to their historically pristine domestic water, and they claim it to be unbearable to use (see Figure 2). Complaints observed include bad water taste, that it is believed to have been established for birth control by destroying male reproductive systems, and carcinogenic upon prolonged use. The main reason arises from all WSSAs (except IRUWASA) having only taken the chlorination step towards treatment, and the fact that gravity-based water supplies have an uncontrolled water flow rate, thus, manual chlorine set doses becomes sporadically unstable. Higher flows are noted at night and morning with relative clear waters, whereas low flows are noted during the day and evening, with higher turbidities (mostly due to involvement of water for agricultural activities upstream). Thus, chlorine demand dramatically changes in response to these changes, thereby exposing domestic water users to extreme events of high and low chlorine doses. With these constraints, many WSSAs are unofficially opting to reduce chlorine set doses, while others prefer not to use it at all for the sake of political issues and the majority of water users' reactions. Thus, the aims of establishing chlorination treatments are compromised, and a sustainable solution is urgently required on this matter.

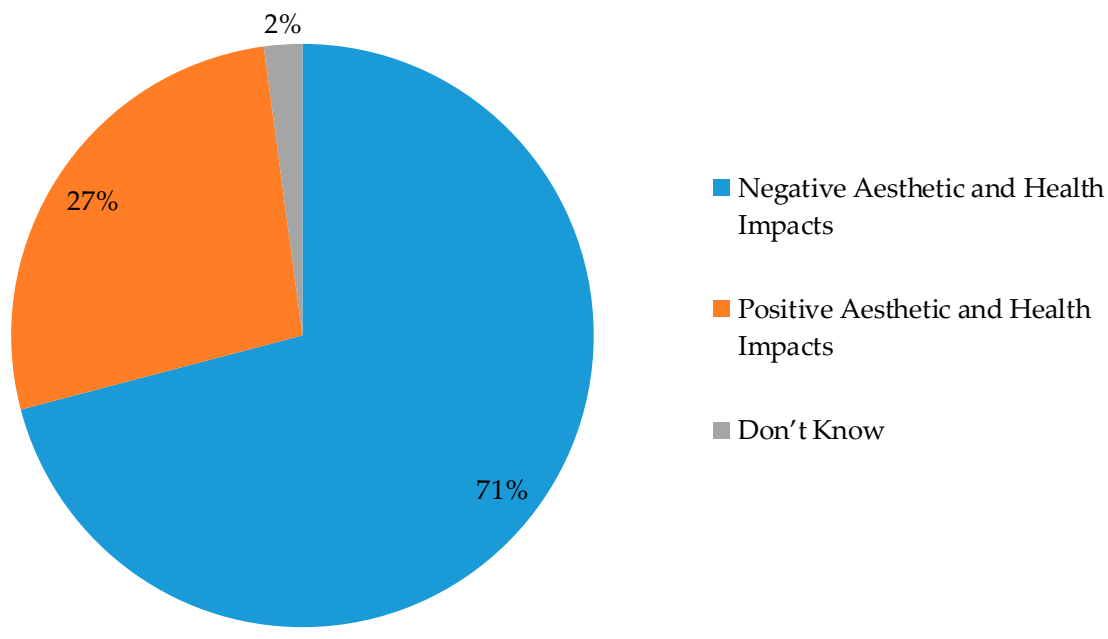

Figure 2. Water quality analysis by perception.

\subsubsection{Water Quality Trends}

In all water quality trend plots (Figures 3-6), groundwater is observed to have a lesser number of samples and, hence, a low number of nonqualifying parameters compared to surface waters. Limited groundwater samples are attributed to privately owned boreholes that are negligibly tested for water quality; the few groundwater sources noted are due to regulatory requirement assessments over several private companies that usually require compliance confirmation to their accrediting organizations. Parameters noted to exceed in groundwater sources were mostly the same for surface water sources, although several unique parameters existed for each source. While the wet season was observed to have a dilution effect on groundwater sources by presenting less nonqualifying parameters, as contrasted by their dry season statistics, surface water sources are characterized by high nonqualifying parameters during the wet season due to interaction with mostly terrestrial rain surface run-off. Useful information obtainable from these plots includes:

i. Microbial quality: Most groundwater sources present limited microbial pollution in both seasons, but surface water sources guarantee microbial contamination in both seasons. Current water quality practices are emphasizing efforts to assess microbial quality in new and developed sources, and while these parameters require strict analytical precautions, it can be concluded 
that they are of no importance to their analysis in surface water sources (unless it intends to assess a microbial treatment practice efficiency), but rather significant in groundwater sources. Many water supply projects are constantly established based on funds and funder's availability. Hence, when surface water sources are preferred, efforts on microbial assessment should be avoided, and treatment practices should be a mandatory part of the project infrastructure. State monitoring programmes that realize on-site water quality assessment can omit microbial analysis in untreated surface water sources/supplies as it increases complications, while the reality is always valid for this source category being vulnerable and containing contaminants.

ii. The trend shows the dominance of certain parameters in either surface or groundwater sources. Since regional water quality laboratories are focusing on their legal sphere of services and the fact that they aim to be accredited, it can be concluded that such laboratories better focus on accrediting respective nonqualifying parameters as a basic criterion. Furthermore, heavy metal assessments can be preferred over most qualifying parameters when there is a limited analytical scope coverage window.

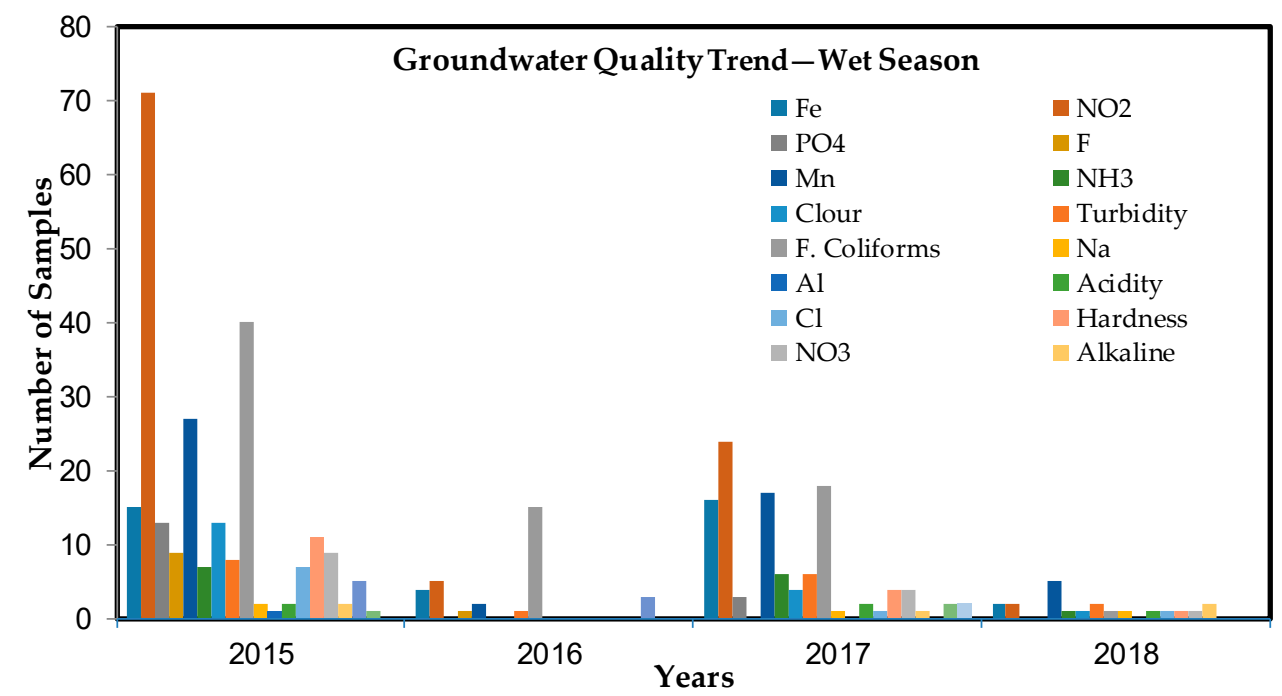

Figure 3. Groundwater quality variations during wet season from 2015 to 2018 (number of nonqualifying parameters, $n=19$ ).

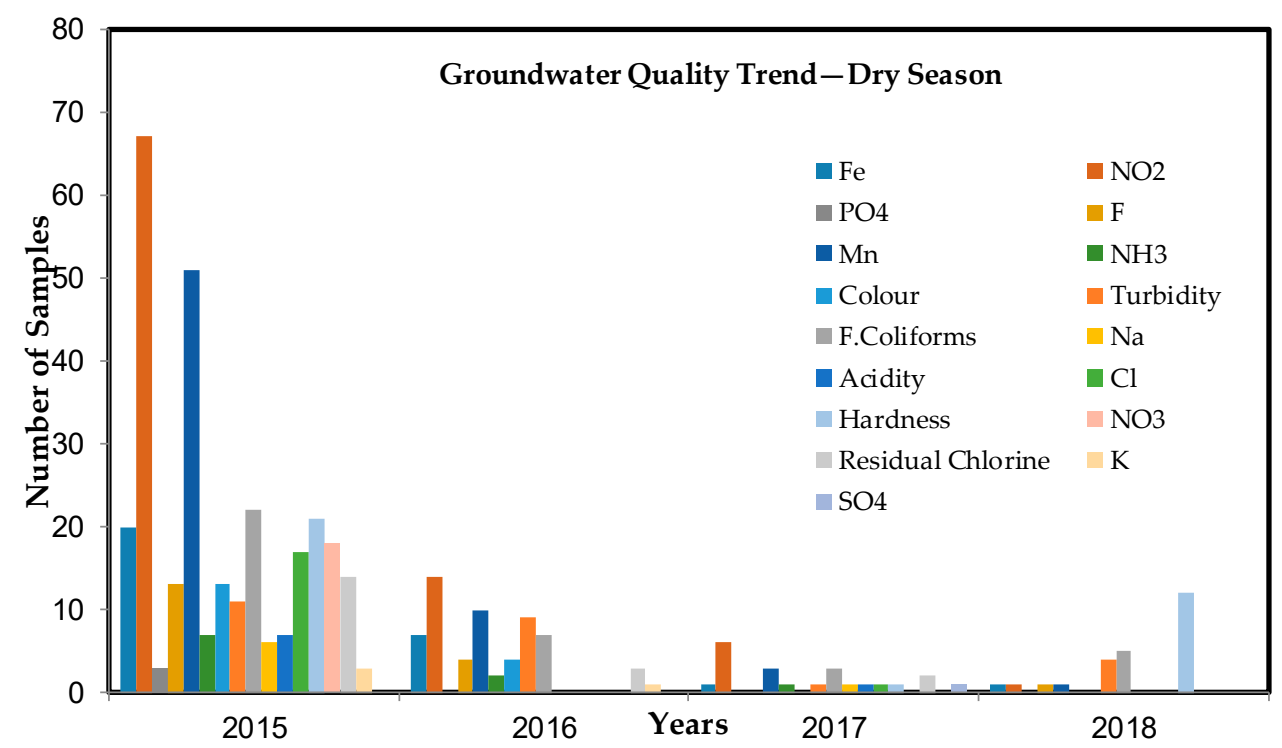

Figure 4. Groundwater quality variations during dry season from 2015 to 2018 (number of nonqualifying parameters, $n=17)$. 


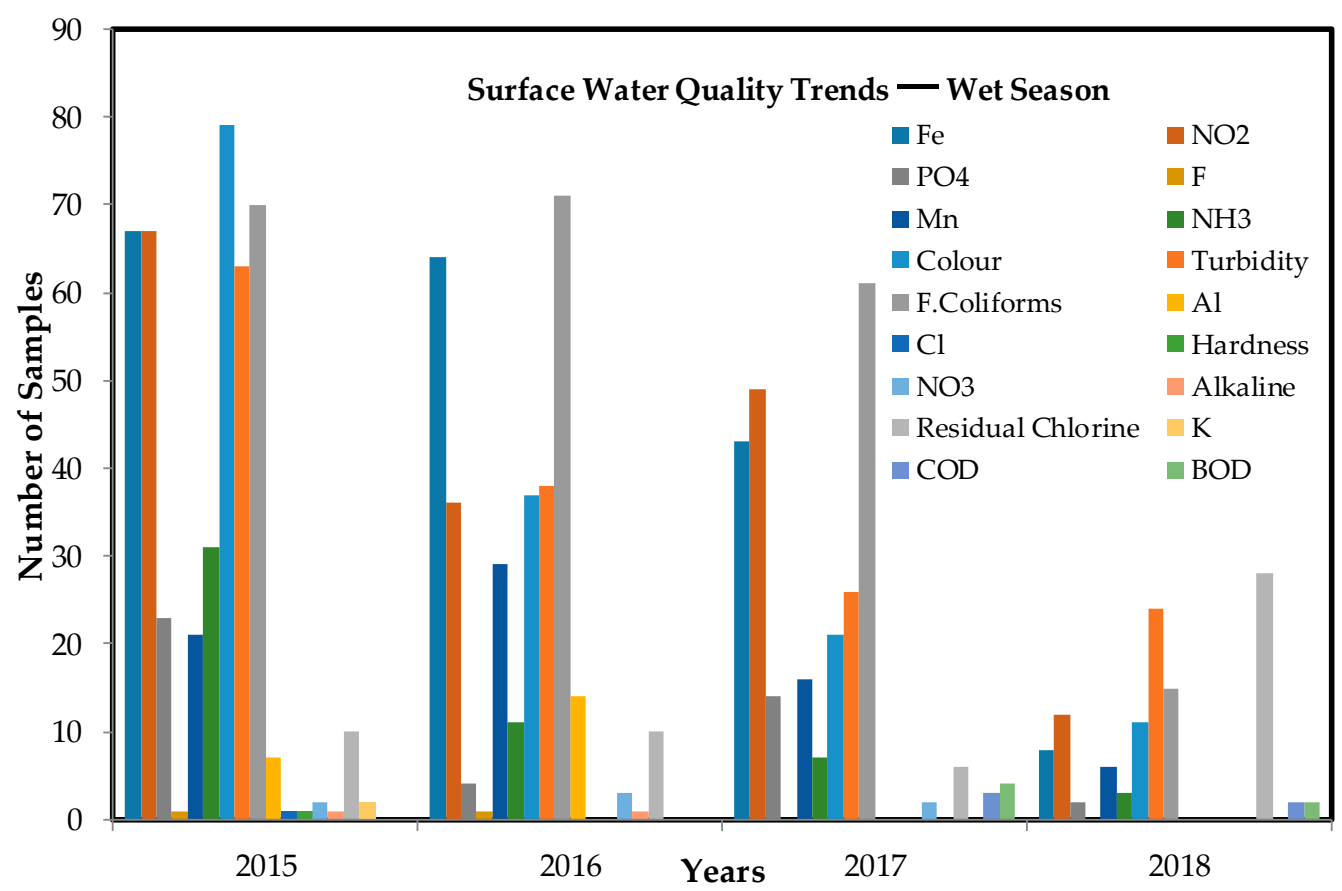

Figure 5. Surface water wuality variations during wet season from 2015 to 2018 (number of nonqualifying parameters, $n=18$ ).

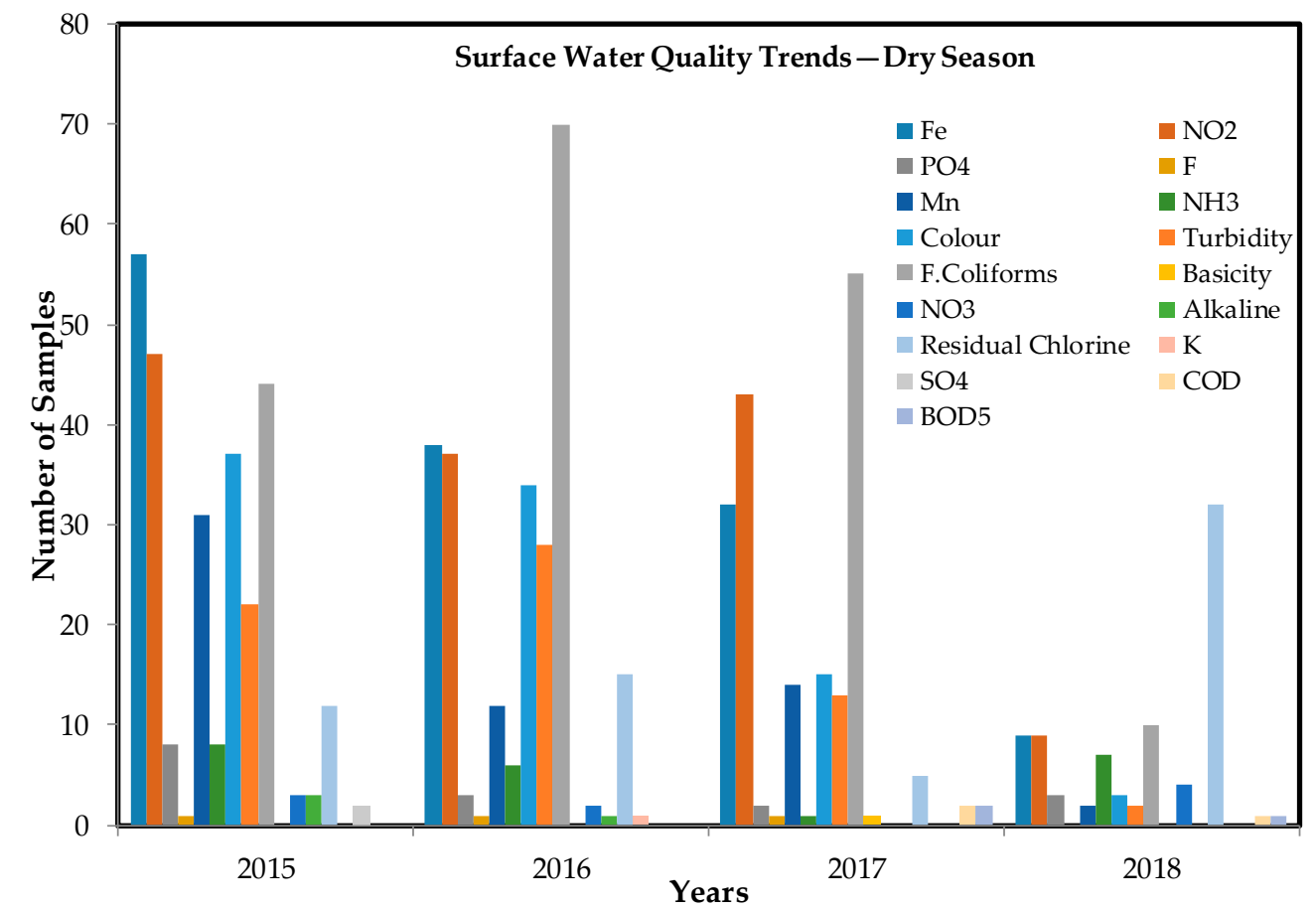

Figure 6. Surface water quality variations during dry season from 2015 to 2018 (number of nonqualifying parameters, $n=17)$. 


\subsubsection{Water Quality Remediation Practices}

\section{Heavy Metal Issues}

Irrespective of any domestic water source origin (ground or surface; public or private), good quality is a prerequisite criterion due to its suitability conformity. Heavy metals are encountered in environmental settings due to their geological conservation; thus, groundwater sources are vulnerable to a large extent. On the other hand, human development has encouraged heavy metal contamination in water sources in a number of ways, these include (i) fertilizer application in irrigation water that interacts with aquifers or becomes transported downstream where domestic applications are realized, (ii) rainwater harvesting through various roof materials, and (iii) corrosion of metallic-based water supply networks [72]. The Ministry of Water [67] demonstrated the significance of assessing heavy metals due to their increasing impacts on public health [73-75]. Similar to other chemical pollutants, heavy metals are bioaccumulated in body tissues and will present their effect at chronic levels [76]. Table 1 shows the status of heavy metals in different sources based on IRUWASA-tested water sources.

Table 1. Heavy metal concentration $(\mathrm{mg} / \mathrm{L})$ in different water sources supplied by IRUWASA.

\begin{tabular}{cccccc}
\hline S/N & Parameter & $\begin{array}{c}\text { Raw Water at } \\
\text { Little Ruaha River }\end{array}$ & $\begin{array}{c}\text { Borehole at } \\
\text { Kibwabwa }\end{array}$ & $\begin{array}{c}\text { Springwater } \\
\text { at Kitwiru }\end{array}$ & Treated Water * \\
\hline 1 & Aluminium & 0.000 & 0.000 & 0.000 & 0.004 \\
2 & Arsenic & 0.000 & 0.000 & 0.000 & 0.000 \\
3 & Barium & 1.000 & 0.000 & 1.000 & 0.000 \\
4 & Cadmium & 0.010 & 0.000 & 0.030 & 0.010 \\
5 & Chromium & 0.000 & 0.000 & 0.000 & 0.000 \\
6 & Cobalt & 0.410 & 0.000 & 0.320 & 0.000 \\
7 & Copper & 0.000 & 0.010 & 0.000 & 0.010 \\
8 & Iron & 0.100 & 0.010 & 0.030 & 0.020 \\
9 & Lead & 0.002 & 0.000 & 0.004 & 0.000 \\
10 & Manganese & 0.025 & 0.007 & 0.045 & 0.000 \\
11 & Mercury & 0.001 & 0.000 & 0.000 & 0.000 \\
12 & Molybdenum & 0.010 & 0.090 & 0.050 & 0.010 \\
13 & Nickel & 0.000 & 0.034 & 0.147 & 0.000 \\
14 & Selenium & 0.005 & 0.001 & 0.042 & 0.000 \\
15 & Silver & 0.020 & 0.000 & 0.000 & 0.000 \\
16 & Zinc & 0.050 & 0.000 & 0.030 & 0.000 \\
\hline
\end{tabular}

* Treated water is a blend of (i) treated Little Ruaha River water, $85 \%$, (ii) springwater, $14 \%$, and (iii) borehole water, $1 \%$.

Heavy metal results with $0.000 \mathrm{mg} / \mathrm{L}$ concentration were implied to be below the analytical detection limit. The concentration of heavy metals followed the order of raw water from Little Ruaha river $>$ spring water $>$ borehole $>>>>$ treated water. Since the high volume of treated Little Ruaha raw water contributes much to final blended water, it was observed that treatment practices employed to eliminate higher river water turbidities (coagulation-flocculation and sedimentation) were also responsible for concurrent elimination of heavy metals [77]. Thus, it can be noted that, while IRUWASA is struggling with turbidity elimination using flocculants, they also realize heavy metal remediation from the same water. Furthermore, when this water (85\%) was mixed with that of spring (14\%) and borehole $(1 \%)$, which contained higher levels of several heavy metals, it resulted in an overall dilution effect and the new blended water was characterized with less to no detectable heavy metal content. While it has been observed as a curse for many WSSAs in Tanzania to encounter very turbid raw water sources, it is now an advantage, as making this water clear makes it free from heavy metals, too. 
Disinfection By-Products (DBPs) Issues

Chlorination is a mandatory treatment stage for many water supply schemes in Tanzania, regardless of any pretreatment means, such as water clarification from high turbidity values. Even in advanced treatment practices that involve turbid water clarification prior to chlorination, organic flocculant residuals play a vital role in the formation of DPBs [78]. However, with such an observation, many remediation approaches are suggested for combating DBP issues: membrane technique is an excellent [79], two-stage or standard treatment, contrasted by rapid [80] in WSSA implementing clarification processes that reduce DBP levels. However, the common and affordable method is household boiling of treated water meant for drinking (Table 2).

Table 2. DBPs (regulated trihalomethanes, THMs) remediation by boiling drinking water.

\begin{tabular}{cccc}
\hline S/N & DBP Species & Efficiency (\%) & Reference \\
\hline 1 & Chloroform (TCM) & $69-97$ & {$[81-83]$} \\
2 & Bromodichloromethane (BDCM) & $68-98$ & {$[81-83]$} \\
3 & Dibromochloromethane (DBCM) & $51-100$ & {$[81-83]$} \\
4 & Bromoform (TBM) & $40-100$ & {$[81-83]$} \\
5 & Sum of 4 THMs (THM4) & $40-98$ & {$[81-83]$} \\
\hline
\end{tabular}

A variation on DPB decrease efficiency was attributed to different boiling appliances in all experiments within five minutes. Useful information in these observations is that, while the state recommends chlorination practices to all public water supplies in favor of preventing endemic disease eruption, individuals can avoid any potential health impact (especially for children and pregnancy) due to DBPs by boiling such water meant for drinking.

\subsection{Quantity Aspect}

Available water resources (ground and surface) experience deteriorating trends, which threatens their reliability because (i) flows across rivers and streams have shifted from continuous to seasonal, and are characterized by rapid drying; (ii) springs that present declined discharges due to dry up affect water resource availability; (iii) groundwater from boreholes have diminished discharges and recharge rates; and (iii) wetlands become overexploited and severely polluted. Climate change, coupled with global overpopulation, is the main reason for observed water resource behaviors [84-86].

\subsubsection{Groundwater}

Tanzania has more than 47 known private groundwater drilling companies [87] that competitively provide relatively affordable services compared to the government Drilling and Dam Construction Agency-DDCA. While DDCA has a remarkable record of this service (Table 3), it can be concluded that groundwater has been adversely exploited under the operation of these companies that stick to profit maximization. In this case, groundwater quantification and, hence, accountability as a water resource becomes poorly managed. Water use permits that are legally granted by a country's water boards have not been successful, as most private companies and clients on drilling normally find this step a setback. Therefore, the many boreholes reported to have been drilled are not reflective of the reality, and many water users are abstracting groundwater without any plausible use control. The government of Tanzania, through the ministry of water, should consider the identification of such illegal drilled boreholes and account for them in available water sources and revenue channels for the promotion of equitable water utilization among the country's dwellers. 
Table 3. Boreholes and their yields from 1999 to 2015 (modified from [88]).

\begin{tabular}{cccc}
\hline Financial Year & Successful Borehole & $\begin{array}{c}\text { Average Yield per Borehole } \\
\text { per Day }\left(\mathbf{m}^{\mathbf{3}} \mathbf{d}\right)\end{array}$ & $\begin{array}{c}\text { Total Yield per Day } \\
\left(\times \mathbf{1 0}^{\mathbf{3}} \mathbf{~ m}^{\mathbf{3}} \mathbf{d} \mathbf{)}\right)\end{array}$ \\
\hline $1998 / 1999$ & 427 & 163.44 & 69.8 \\
$1999 / 2000$ & 503 & 120.24 & 60.5 \\
$2000 / 2001$ & 352 & 179.04 & 63 \\
$2001 / 2002$ & 331 & 140.88 & 46.6 \\
$2002 / 2003$ & 358 & 123.12 & 44.1 \\
$2003 / 2004$ & 417 & 136.32 & 56.8 \\
$2004 / 2005$ & 423 & 123.45 & 52.2 \\
$2005 / 2006$ & 401 & 150 & 60.2 \\
$2006 / 2007$ & 401 & 242.13 & 97.1 \\
$2007 / 2008$ & 419 & 228 & 95.5 \\
$2008 / 2009$ & 380 & 133.8 & 50.8 \\
$2009 / 2010$ & 254 & 142.10 & 36.1 \\
$2010 / 2011$ & 219 & 102.00 & 22.3 \\
$2011 / 2012$ & 226 & 249.3 & 56.3 \\
$2012 / 2013$ & 205 & 137.66 & 28.2 \\
$2013 / 2014$ & 116 & 142.95 & 16.6 \\
$2014 / 2015$ & 285 & 166.85 & 47.6 \\
\hline Total & 5717 & $\mathbf{2 6 8 1 . 2 8}$ & $\mathbf{9 0 3 . 7}$ \\
\hline
\end{tabular}

For the past 17 years (1999 to 2015), DDCA was able to accomplish 5700 boreholes in Tanzania with an average of $86 \%$ success rate, capable of providing $903,700 \mathrm{~m}^{3} / \mathrm{d}$ yields. It was declared that $27 \mathrm{~L}$ to $200 \mathrm{~L}$ per capita per day $\left(0.027 \mathrm{~m}^{3} / \mathrm{d}\right.$ to $\left.0.2 \mathrm{~m}^{3} / \mathrm{d}\right)$ are required for drinking, sanitation, cooking, and bathing [89]. Currently, there are about 61,000,000 Tanzanians [90], whom altogether would require a total of $1,647,000$ to $12,200,000 \mathrm{~m}^{3} / \mathrm{d}$ freshwater. Thus, an average of $6,923,500 \mathrm{~m}^{3} / \mathrm{d}$ freshwater is required to sustain the current daily demand. As of 2005, the Ministry of Water had a database of 9242 drilled boreholes [91], in which DDCA contributed 2811 (30.4\%), since private drilling companies are preferred by individuals due to their affordability (which is also suspected to affect the quality of the work). Thus, at least each year, a total of 1320 boreholes are accomplished (even though [91] determined an annual requirement of at least 1600 boreholes drilling). Using such an estimation for the period of 1999 to 2018, at least 26,406 boreholes are available in Tanzania. In fact, as of 2009, private enterprises contributed about 9000 boreholes from Dar es Salaam city alone [92]. Since boreholes are drilled to operate for 20 years to 50 years [93], then a total of 4,174,060 $\mathrm{m}^{3} / \mathrm{d}$ is obtainable and capable of satisfying more than $60 \%$ of current freshwater demands for all Tanzanians. This estimate excludes shallow wells and unreported boreholes, which significantly contribute to the water supply sector; in this case, $25 \%$ reported as a contribution of boreholes in the domestic water supply [94] is rather due to poor management of abstracted groundwater.

During site visits, many hotels, lodges, and guest houses were characterized by the possession of boreholes as a secondary water source, i.e., in addition to the one supplied by WSSAs; however, such groundwater sources were significantly preferred over public water supplies, as they could meet customer requirements at an affordable cost. It was observed that individual guests were utilizing more water under the claim that they pay for it. Thus, groundwater resources are inequitably accessed by many Tanzanians in the business intervention model. Furthermore, since only WSSAs are legally permitted to realize water supplies, many individuals with private wells are unofficially doing the same under civilian support. The worst scenario arises from the government's (Ministry of Water) recent statement over an intention for the authorization of free groundwater access for household use. Thus, it contradicts WSSAs and water basin supply businesses/fraud and revenue collection, respectively [48]. In fact, the majority preferred groundwater due to clarity issues, as WSSAs utilizing surface water sources are facing significantly inadequate supply and poor quality (e.g., very turbid water during rainy seasons; chemical residuals from treatment practices). 
Thus, this paper suggests that no permits on groundwater abstraction shall be a setback in drilled and ongoing drilling business, but for each borehole there should be water abstraction control and charges by means of metering; well owners shall then not be prohibited from selling their water, but only the agreed price must be used and collected by the governmental control body (e.g., Basin Water Boards and WSSAs based on their legal spheres of influence). The same should be done to bottled water companies that maximize their profit on this common good. Groundwater abstraction for irrigation shall be exempted due to the fate of irrigation waters [95] and the significance of agriculture to the country's economy, unless aquifers get compromised in a defective manner that threatens domestic water supplies.

\subsubsection{Surface Water}

Generally, Table 4 shows that rural water supplies are costly compared to urban-based WSSA services. Furthermore, while public domestic point connections are aimed at serving many people at an affordable cost, the opposite is observed due to most points having higher or comparable costs to those of private-based points. These observations were attributed by many rural-based WSSAs ensuring the availability of funds for sustainable water supply operations; hence, relatively higher tariffs were to be subjected to the large public-oriented community. In fact, private connections are much preferred as their revenues are exclusively collected by WSSA management, whereas public connection requires a public kiosk operator who must receive a $20 \%$ to $50 \%$ share of the collected tariff.

Table 4. Water supply and sanitation authority (WSSA)/community-owned water supply organization (COWSO)'s current practices (as of April 2019).

\begin{tabular}{|c|c|c|c|c|c|c|c|c|c|}
\hline \multirow{2}{*}{$\mathbf{S} / \mathbf{N}$} & \multirow{2}{*}{ WSSA/COWSO } & \multirow{2}{*}{ Source } & \multirow{2}{*}{$\begin{array}{l}\text { Supply } \\
\text { Mode }\end{array}$} & \multirow{2}{*}{$\begin{array}{l}\text { Treatment } \\
\text { Practices }\end{array}$} & \multirow{2}{*}{$\begin{array}{c}\text { Population } \\
\text { Served }\end{array}$} & \multicolumn{2}{|c|}{ Connection } & \multicolumn{2}{|c|}{ Tariff (TShs/m ${ }^{3}$ ) } \\
\hline & & & & & & Public & Private & Public & Private \\
\hline 1 & IIRUWASA-(M) & $\mathrm{R}, \mathrm{BH}$, and $\mathrm{Sp}$ & $\mathrm{P}$ & $\begin{array}{c}\text { F, SF, C, } \\
\text { and B }\end{array}$ & 138,000 & 128 & 24,553 & 1000 & 1685-2035 \\
\hline 2 & Kilolo-(D) & St & G and $P$ & C & 28,000 & 70 & 724 & 1000 & 485 \\
\hline 3 & Mafinga-Smt & St and Sp & G and $P$ & $\mathrm{C}$ & 72,000 & 1 & 3768 & 500 & $790-930$ \\
\hline 4 & Ilula-Smt & St & G & C & 40,700 & 56 & 1186 & $\begin{array}{c}1500-2500 \\
1000^{\mathrm{FR}}\end{array}$ & $\begin{array}{c}500-600 \\
5000^{\mathrm{FR}}\end{array}$ \\
\hline 5 & Magubike-(R) & $\mathrm{R}$ & G & $\mathrm{C}$ & 15,000 & 62 & 187 & 1500 & 1500 \\
\hline 6 & Ifunda-(R) & Sp & $\mathrm{P}$ & $\mathrm{C}$ & 6000 & 20 & 5 & 2500 & 2000 \\
\hline 7 & Kidabaga-(R) & $\mathrm{R}$ & $\mathrm{P}$ & $\mathrm{C}$ & 2300 & 13 & 40 & 2500 & 2500 \\
\hline 8 & Ng'uruhe-(R) & St & G & $\mathrm{C}$ & 2900 & 48 & 78 & $2000^{\mathrm{FR}}$ & $5000^{\mathrm{FR}}$ \\
\hline 9 & Ihimbo-(R) & St & G & $\mathrm{C}$ & 2700 & 18 & 66 & 1000 & 5000 \\
\hline 10 & Mgama-(R) & St & G & $\mathrm{C}$ & 1000 & 17 & 110 & $1000^{\mathrm{FR}}$ & $1667^{\mathrm{FR}}$ \\
\hline 11 & Irindi-(R) & St & G & $\mathrm{C}$ & 2400 & 16 & 27 & 1000 & 5000 \\
\hline
\end{tabular}

M-municipal, (D)—district, Smt—small town, (R)—rural, Rriver, BH—borehole, Sp—spring, St—stream, P-pumping, G-gravity, F-flocculation, SF-sand filtration, C-chlorination, B-blending, FR-flat rate tariff payment per household on a monthly basis (i.e., not $\mathrm{TSh} s / \mathrm{m}^{3}$ ).

Water supply through pumping modes in rural areas had a higher tariff compared to rural gravity-based water supplies; in these WSSAs, water management is improved and financial collections reflect operation and maintenance expenses. On the other hand, gravity-based water supplies are facing difficulties in financial collections, as the majority of public water users take water for granted, and believe that operating costs are far lower than the current tariff. Hence, management of rural gravity-based water supplies become deprived and threaten the sustainability of these projects. Such management practices are further related to water loss in most parts of the supply network from these highly numbered gravity water supplies, causing loss of permitted water quantities for abstraction and subjecting downstream users to water scarcity vulnerabilities; the situation becomes worse in flat rate tariff-oriented WSSAs, where water management is extremely poor. Water treatment and supply modes presented by urban WSSA are relatively advanced and characterized by the highest operation costs, and yet the supplied water for town dwellers is relatively cheap compared to rural settings, so a lesson can be learned here and propagated in all rural-based WSSAs for effective safe water provision at an affordable cost. 
Socioeconomically, an affordable tariff should consider good practices from mutual or integrated stakeholders' participation. It should include an application of water resources protection and enforceable pollution prevention environmental laws, backed up with quality management approaches [96]. To support such WSSAs in managerial and technical operating areas and tariff regulations, regulatory authorities that exercise multiple factors before authorization of a proposed tariff [97] should be employed. This should also reflect underlying circumstances in the consideration of water quality and quantity, and their associated treatment and supply modalities.

\section{Conclusions}

Generally, results show that the water supply sector in terms of quality and a quantity aspects is poorly addressed in regards to sustainable domestic water concepts. Systematic analytical approaches from this study suggest that water resources should be centralized to state governing bodies in terms of supply for surface and groundwater among all citizens. This will be achieved through policies, rules, and regulations under respective ministries, so that only public water supply and sanitation authorities are allowed to control domestic water provisions. In order to achieve this, the following will be put into consideration for the implementation of WSSAs as a national strategy for sustainable domestic water management:

$\bigcirc$ Groundwater abstraction should be controlled through metering and, hence, charging a reasonable tariff that will consider owners of invested well infrastructure, who shall be permitted to sell such water to neighbors to enhance service, while controlling abstraction charges by respective WSSAs.

- Treatment of turbid surface water sources should be preferred as the process concurrently eliminates heavy metals in the final water; furthermore, other polluted sources can be subjected to blending practices using treated water to reach acceptable final contaminant limits prior to supply.

- Water quality assessment can be enhanced among private water source owners if water sampling is done by such an owner using a simplified procedure presented to them and a relevant state sampling protocol.

- Rural-based WSSAs/COWSOs must learn and implement best practices from urban WSSAs who, irrespective of higher operation and maintenance expenses, still provide water to urban communities at relatively low tariff cost compared to rural water suppliers.

- The diversity of water quality laboratories should be eliminated in order to improve management and minimize operations expenses while maximizing analytical capabilities. Only three to five fully furnished water laboratories are satisfactory in the country. This is possible if offices at regional and or district levels are established to facilitate in situ analysis of nonpreservable parameters and sample preservations for transportation to such designated laboratories.

Funding: This research was funded by The African Development Bank (AfDB), grant number 2100155032816.

Acknowledgments: Rajabu Rajabu Mohamedi, Emanus Emmanuel Kamulasi, and Dativa Paschal Makundi (Iringa Water Quality Laboratory, Water Quality Services Division, Ministry of Water, P.O. Box 570 Iringa Tanzania); Ramadhani Zahoro Ramadhani and Hilbamanya I. Barhe (Central Water Quality Laboratory, Water Quality Services Division, Ministry of Water, P.O. Box 9153 Dar Es Salaam Tanzania) are acknowledged for their analytical work support. Anna Mhongole (Faculty of Education, Mkwawa University College of Education, MUCE, P.O. Box 2513 Iringa Tanzania) is acknowledged for her insightful comments during the preparation of the manuscript. The manuscript was improved by insightful comments from anonymous reviewers of J-Multidisciplinary Scientific Journal

Conflicts of Interest: The author declares no conflict of interest.

\section{References}

1. Environmental Protection Agency (EPA). The Water Cycle and Water Conservation. 2015. Available online: https://www.epa.gov/sites/production/files/2015-08/documents/mgwc-gwa1.pdf (accessed on 9 April 2019).

2. Spellman, F.R. The Science of Water: Concepts and Applications; CRC Press: Boca Raton, FL, USA, 2018. [CrossRef] 
3. Vörösmarty, C.J.; Lévêque, C.; Revenga, C. Fresh Water. Chapter 7 in Millennium Ecosystems Assessment, Volume 1 Ecosystems and Human Well-Being: Current State and Trends. 2005. Available online: https: //www.millenniumassessment.org/documents/document.276.aspx.pdf (accessed on 9 April 2019).

4. United Nations. Water Quality and Sanitation. 2010. Available online: https://www.un.org/ waterforlifedecade/swm_cities_zaragoza_2010/pdf/01_water_quality_and_sanitation.pdf (accessed on 9 April 2019).

5. Kummu, M.; Guillaume, J.H.A.; de Moel, H.; Eisner, S.; Flörke, M.; Porkka, M.; Siebert, S.; Veldkamp, T.I.E.; Ward, P.J. The world's road to water scarcity: Shortage and stress in the 20th century and pathways towards sustainability. Sci. Rep. 2016, 6, 38495. [CrossRef] [PubMed]

6. Dilling, L.; Daly, M.E.; Kenney, D.A.; Klein, R.; Miller, K.; Ray, A.J.; Travis, W.R.; Wilhelmi, O. Drought in urban water systems: Learning lessons for climate adaptive capacity. Clim. Risk Manag. 2019, 23, 32-42. [CrossRef]

7. Wang, X.; Yang, H.; Shi, M.; Zhou, D.; Zhang, Z. Managing stakeholders' conflicts for water reallocation from agriculture to industry in the Heihe River Basin in Northwest China. Sci. Total Environ. 2015, 505, 823-832. [CrossRef] [PubMed]

8. Johnson, H.; South, N.; Walters, R. Eco-crime and fresh water. In Greening Criminology in the 21st Century: Contemporary Debates and Future Directions in the Study of Environmental Harm; Taylor and Francis: Abingdon, UK, 2017; pp. 133-146. [CrossRef]

9. Marion, P.; Bernela, B.; Piccirilli, A.; Estrine, B.; Patouillard, N.; Guilbot, J.; Jérôme, F. Sustainable chemistry: How to produce better and more from less? Green Chem. 2017, 19, 4973-4989. [CrossRef]

10. Taks, J. Water-Worlds: How to Research Under the Umbrella of Sustainable Development Being Aware of Its Multiple Ambiguities? In Sustainable Development Research and Practice in Mexico and Selected Latin American Countries; Springer: Cham, Switzerland, 2018; pp. 411-421. [CrossRef]

11. Jedd, T. Management of Transboundary Water Resources under Scarcity; Elsevier Publishing House: Great Britain, Oxford, UK, 2018. [CrossRef]

12. Hu, T.; Pang, C.; Zhou, X. Say No to the Thirsty Planet: Too Few Freshwater for the Daily Life of Human Beings. In IOP Conference Series: Earth and Environmental Science; IOP Publishing: Ordos, China, 2018; Volume 170, p. 022116. [CrossRef]

13. Hertel, T.; Liu, J. Implications of water scarcity for economic growth. In Economy-Wide Modeling of Water at Regional and Global Scales; Springer: Singapore, 2019; pp. 11-35. [CrossRef]

14. Murray, K.; Roux, D.J.; Nel, J.L.; Driver, A.; Freimund, W. Absorptive capacity as a guiding concept for effective public sector management and conservation of freshwater ecosystems. Environ. Manag. 2011, 47, 917-925. [CrossRef]

15. Shiva, V. Water Wars: Privatization, Pollution, and Profit. North Atlantic Books. 2016. Available online: http://courseresources.mit.usf.edu/sgs/ang6469/canvas/module_7/read/The_Sacred_Waters.pdf (accessed on 13 May 2019).

16. Vörösmarty, C.J.; Hoekstra, A.Y.; Bunn, S.E.; Conway, D.; Gupta, J. What scale for water governance. Science 2015, 349, 478-479. [CrossRef]

17. Barlow, M.; Clarke, T. Blue Gold: The Battle Against Corporate Theft of the World's Water; Taylor \& Francis, Routledge: London, UK, 2017. [CrossRef]

18. Rahaman, M.M.; Varis, O. The ethical perspective of water: Dilemmas and future challenges. Sustain. Dev. Energywater Environ. Syst. 2005, 2, 39-51.

19. Mooney, H.; Cropper, A.; Reid, W. Confronting the human dilemma. Nature 2005, 434, 561. [CrossRef]

20. Swain, A. Water and post-conflict peacebuilding. Hydrol. Sci. J. 2016, 61, 1313-1322. [CrossRef]

21. Song, X.; Ravesteijn, W. Dilemmas in water systems development in China. In What Is Sustainable Technology? Taylor \& Francis, Routledge: London, UK, 2017; pp. 213-234.

22. Yadav, A.; Das, A.K.; Roy, R.B.; Chatterjee, A.; Allen, J.K.; Mistree, F. Identifying and Managing Dilemmas for Sustainable Development of Rural India. In ASME 2017 International Design Engineering Technical Conferences and Computers and Information in Engineering Conference; American Society of Mechanical Engineers, ASME Publishing House: Cleveland, OH, USA, 2017; p. V007T06A017. Available online: http://sunmoksha.com/ Publication/Ashok\%20Das\%202017\%20DilemmaTriangle\%20IDETC2017\%202017-08.pdf (accessed on 18 May 2019). 
23. Yihdego, Z. The Fairness 'Dilemma' in Sharing the Nile Waters: What Lessons from the Grand Ethiopian Renaissance Dam for International Law? Brill Res. Perspect. Int. Water Law 2017, 2, 1-80. [CrossRef]

24. Le Vernoy, A. The Trade and Water Nexus; ADBI Working Paper Series No. 669; EconStor Publishing House: Tokyo, Japan, 2017; Available online: http://hdl.handle.net/10419/163168 (accessed on 22 May 2019).

25. White, D.J.; Hubacek, K.; Feng, K.; Sun, L.; Meng, B. The Water-Energy-Food Nexus in East Asia: A tele-connected value chain analysis using inter-regional input-output analysis. Appl. Energy 2018, 210, 550-567. [CrossRef]

26. Zhao, X.; Liu, J.; Liu, Q.; Tillotson, M.R.; Guan, D.; Hubacek, K. Physical and virtual water transfers for regional water stress alleviation in China. Proc. Natl. Acad. Sci. USA 2015, 112, 1031-1035. [CrossRef] [PubMed]

27. Wichelns, D. Virtual water and water footprints do not provide helpful insight regarding international trade or water scarcity. Ecol. Indic. 2015, 52, 277-283. [CrossRef]

28. Lyakurwa, F.S.; Song, G.; Chen, J. Quantitative modeling of freshwater stress in the nine water basins of Tanzania. Chin. J. Popul. Resour. Environ. 2014, 12, 309-315. [CrossRef]

29. Lyatuu, E.T.; Nie, F.; Fang, C. Implication of the economic stability on the poverty-agriculture development nexus in Tanzania. Int. J. Agric. Food Res. 2016, 4. [CrossRef]

30. Suleiman, R.A. Assessing and Controlling Bio-Deterioration of Maize in Tanzania; IOWA State University Publisher: Iowa, IA, USA, 2016. [CrossRef]

31. Lugendo, P.; Tsegaye, T.; Wortman, C.J.; Neale, C.M. Climate Variability Implications for Maize Yield Food Security and Rural Poverty in Tanzania. In Available at SSRN 3233487; SSRN Publishing House: Rochester, NY, USA, 2017. [CrossRef]

32. Makulilo, A.B. Against Foreign Capital: The Populist Temptation in Tanzania. Whitehead J. Dipl. Int'l Rel. 2017, 18, 49 .

33. Tibesigwa, B.; Siikamäki, J.; Lokina, R.; Alvsilver, J. Naturally available wild pollination services have economic value for nature dependent smallholder crop farms in Tanzania. Sci. Rep. 2019, 9, 3434. [CrossRef]

34. Leyaro, V.; Morrissey, O.; Boulay, B. Food Crop Production in Tanzania: Evidence from the 2008/09 National Panel Survey. 2014. Available online: http://hdl.handle.net/20.500.12018/2680 (accessed on 29 May 2019).

35. Alam, F.; Myovella, G. Causality between Agricultural Exports and GDP and its implications for Tanzanian economy. J. Econ. Financ. Account. 2017, 3, 1-18. [CrossRef]

36. Mkonda, M.; He, X. Vulnerability assessment of the livelihoods in Tanzania's semi-arid agro-ecological zone under climate change scenarios. Climate 2018, 6, 27. [CrossRef]

37. Katko, T.S.; Rajala, R.P. Priorities for freshwater use purposes in selected countries with policy implications. Int. J. Water Resour. Dev. 2005, 21, 311-323. [CrossRef]

38. Tanzania National Water Policy NAWAPO. 2002. Available online: http://maji.go.tz/uploads/publications/ sw1552315386-NAWAPO.pdf (accessed on 4 July 2019).

39. Jiménez, A.; Pérez-Foguet, A. Building the role of local government authorities towards the achievement of the human right to water in rural Tanzania. In Natural Resources Forum; Blackwell Publishing Ltd.: Oxford, UK, 2010; Volume 34, pp. 93-105. [CrossRef]

40. Saladi, J.A.; Salehe, F.S. Assessment of Water Supply and Its Implications on Household Income in Kabuku Ndani Ward, Handeni District, Tanzania. 2018. Available online: http://www.suaire.suanet.ac.tz: 8080/xmlui/handle/123456789/2229 (accessed on 10 June 2019).

41. Chumbula, J.J.; Massawe, F.A. The role of local institutions in the creation of an enabling environment for water project sustainability in Iringa District, Tanzania. Environ. Socio-Econ. Stud. 2018, 6, 1-10. [CrossRef]

42. Ngasala, T.M.; Masten, S.J.; Phanikumar, M.S.; Mwita, E.J. Analysis of water security and source preferences in rural Tanzania. J. Watersanitation Hyg. Dev. 2018, 8, 439-448. [CrossRef]

43. Kooy, M.; Walter, C.T.; Prabaharyaka, I. Inclusive development of urban water services in Jakarta: The role of groundwater. Habitat Int. 2018, 73, 109-118. [CrossRef]

44. Elisante, E.; Muzuka, A.N. Assessment of sources and transformation of nitrate in groundwater on the slopes of Mount Meru, Tanzania. Environ. Earth Sci. 2016, 75, 277. [CrossRef]

45. Chacha, N.; Njau, K.N.; Lugomela, G.V.; Muzuka, A.N. Hydrogeochemical characteristics and spatial distribution of groundwater quality in Arusha well fields, Northern Tanzania. Appl. Water Sci. 2018, 8, 118. [CrossRef] 
46. Figoli, A.; Bundschuh, J.; Hoinkis, J. Fluoride, uranium and arsenic: Occurrence, mobility, chemistry, human health impacts and concerns. In Membrane Technologies for Water Treatment; CRC Press: Boca Raton, FL, USA, 2016; pp. 3-19. [CrossRef]

47. Goeller, D. Investigation of Water Quality and Availability in Rural Tanzanian Villages. Doctoral Dissertation, The Ohio State University, Columbus, OH, USA, 2017. Available online: http://hdl.handle.net/1811/80691 (accessed on 12 June 2019).

48. Komakech, H.C.; de Bont, C. Differentiated access: Challenges of equitable and sustainable groundwater exploitation in Tanzania. Water Altern. 2018, 11, 623.

49. Yihdego, Y.; Paffard, A. Hydro-engineering solution for a sustainable groundwater management at a cross border region: Case of Lake Nyasa/Malawi basin, Tanzania. Int. J. Geo-Eng. 2016, 7, 23. [CrossRef]

50. Safeeq, M.; Fares, A. Groundwater and surface water interactions in relation to natural and anthropogenic environmental changes. In Emerging Issues in Groundwater Resources; Springer: Cham, Switzerland, 2016; pp. 289-326. [CrossRef]

51. De Bont, C.; Komakech, H.C.; Veldwisch, G.J. Neither modern nor traditional: Farmer-led irrigation development in Kilimanjaro Region, Tanzania. World Dev. 2019, 116, 15-27. [CrossRef]

52. Nakawuka, P.; Langan, S.; Schmitter, P.; Barron, J. A review of trends, constraints and opportunities of smallholder irrigation in East Africa. Glob. Food Secur. 2018, 17, 196-212. [CrossRef]

53. Theis, S.; Lefore, N.; Meinzen-Dick, R.; Bryan, E. What happens after technology adoption? Gendered aspects of small-scale irrigation technologies in Ethiopia, Ghana, and Tanzania. Agric. Hum. Values 2018, 35, 671-684. [CrossRef]

54. Gudaga, J.L.; Kabote, S.J.; Tarimo, A.K.; Mosha, D.B.; Kashaigili, J.J. Groundwater Users' Awareness of Water Institutions in Tanzania: A Case Study of Mbarali District, Mbeya Region. 2018. Available online: http://www.suaire.suanet.ac.tz:8080/xmlui/handle/123456789/2076 (accessed on 12 June 2019).

55. Biazin, B.; Sterk, G.; Temesgen, M.; Abdulkedir, A.; Stroosnijder, L. Rainwater harvesting and management in rainfed agricultural systems in sub-Saharan Africa-A review. Phys. Chem. Earthparts A/B/C 2012, 47, 139-151. [CrossRef]

56. Han, M.Y. Rainwater Harvesting Potential and Management Strategies for Sustainable Water Supply in Tanzania. Doctoral Dissertation, Seoul National University, Seoul, Korea, 2016. Available online: http://hdl.handle.net/10371/118728 (accessed on 15 June 2019).

57. Marwa, J.; Lufingo, M.; Noubactep, C.; Machunda, R. Defeating fluorosis in the East African Rift Valley: Transforming the Kilimanjaro into a rainwater harvesting park. Sustainability 2018, 10, 4194. [CrossRef]

58. Ndé-Tchoupé, A.I.; Tepong-Tsindé, R.; Lufingo, M.; Pembe-Ali, Z.; Lugodisha, I.; Mureth, R.I.; Nkinda, M.; Marwa, J.; Gwenzi, W.; Rahman, M.A.; et al. White teeth and healthy skeletons for all: The path to universal fluoride-free drinking water in Tanzania. Water 2019, 11, 131. [CrossRef]

59. Mwamila, T.B.; Han, M.Y.; Katambara, Z. Strategy to Overcome Barriers of Rainwater Harvesting, Case Study Tanzania. J. Geosci. Environ. Prot. 2016, 4, 13-23. [CrossRef]

60. Matojo, N.D. Rastapodidae fam. nov. of "Harrowfoot Frogs"(Anura: Neobatrachia) inferred from Breviceps mossambicus re-description (formerly in Brevicipitidae) from Tanzania. J. Biol. Nat. 2015, 200-205. Available online: http://www.ikprress.org/index.php/JOBAN/article/view/1393 (accessed on 16 June 2019).

61. American Water Works Association, American Public Works Association, Water Environment Federation. Standard Methods for the Examination of Water and Wastewater; APHA Publisher: Wshington, DC, USA, 2017; ISBN(s) 9781625762405.

62. TZS 789:2016-EAS 12. Potable Water Specification, Tanzania Bureau of Standards; TBS: Dar es Salaam, Tanzania, 2014.

63. Tanzania Water Supply and Sanitation Act of 2019. Available online: http://www.maji.go.tz/ uploads/publications/en1547640088-1542978073-BILL\%20THE\%20WATER\%20SUPPLY\%20AND\% 20SANITATION\%20ACT,\%202018.pdf (accessed on 20 June 2019).

64. Tanzania Water Supply and Sanitation Act of 2009. Available online: http://www.maji.go.tz/uploads/ publications/en1547641391-THE\%20WATER\%20SUPPLY\%20\%20AND\%20SANITATION\%20ACT\% 20NO\%2012\%20OF\%202009.pdf (accessed on 20 June 2019).

65. Tanzania Water Resources Management Act of 2009. Available online: http:/www.maji.go.tz/uploads/ publications/en1547642040-THE\%20WATER\%20RESOURCES\%20MANAGEMENT\%20ACT\%20NO. \%2011\%20OF\%202009-compressed.pdf (accessed on 20 June 2019). 
66. Nkamleu, G.; Kamgnia, B. Uses and Abuses of Per-Diems in Africa: A Political Economy of Travel Allowances. African Development Bank Group AfDB Working Paper, 196. , 2014. Available online: https://www.afdb.org/fileadmin/uploads/afdb/Documents/Publications/Working_Paper_196_-_Uses_ and_Abuses_of_Per-diems_in_Africa-_A_Political_Economy_of_Travel_Allowances.pdf (accessed on 22 June 2019).

67. Ministry of Water and Irrigation MoW. National Guideline on Drinking Water Monitoring and Reporting. Volume 3: Main Document. 2018. Available online: http://maji.go.tz/uploads/publications/sw1552468165National\%20Guideline\%20on\%20Drinking\%20Water\%20Quality\%20Monitoring\%20and\%20Reporting. pdf (accessed on 20 June 2019).

68. Lufingo, M. The Fate of Water Quality Sector in Developing Countries. International Journal of Advanced Research and Publications (IJARP) Volume 3-Issue 4, April 2019 Edition, 86-90 \#ijarporg. , 2019. Available online: http://www.ijarp.org/online-papers-publishing/apr2019.html (accessed on 7 May 2019).

69. Energy and Water Utilities Regulatory Authority. Water Utilities Performance Review Report for the FY 2917/18; Regional and National Project Water Utilities; EWURA: Dar es Salaam, Tanzania, 2018; pp. 21-22.

70. Mohamed, H.; Brown, J.; Njee, R.M.; Clasen, T.; Malebo, H.M.; Mbuligwe, S. Point-of-use chlorination of turbid water: Results from a field study in Tanzania. J. Water Health 2015, 13, 544-552. [CrossRef]

71. Wang, A. Notes from the field: Chlorination strategies for drinking water during a cholera epidemic-Tanzania, 2016. MMWR Morb. Mortal. Wkly. Rep. 2016, 65. [CrossRef]

72. Elumalai, V.; Brindha, K.; Lakshmanan, E. Human exposure risk assessment due to heavy metals in groundwater by pollution index and multivariate statistical methods: A case study from South Africa. Water 2017, 9, 234. [CrossRef]

73. Ghaderpoori, M.; Kamarehie, B.; Jafari, A.; Ghaderpoury, A.; Karami, M.A. Heavy metals analysis and quality assessment in drinking water-Khorramabad city, Iran. Data Brief 2018, 16, 658-692. [CrossRef]

74. Hofman-Caris, R.; Bertelkamp, C.; de Waal, L.; van den Brand, T.; Hofman, J.; van der Aa, R.; van der Hoek, J.P. Rainwater Harvesting for Drinking Water Production: A Sustainable and Cost-Effective Solution in The Netherlands? Water 2019, 11, 511. [CrossRef]

75. Liu, Q.; Han, W.; Han, B.; Shu, M.; Shi, B. Assessment of heavy metals in loose deposits in drinking water distribution system. Environ. Monit. Assess. 2018, 190, 388. [CrossRef]

76. Bungudu, J.I.; Shuaibu, L.; Mohammed, U.F.; Alkali, M. Heavy Metals Analysis in Human Body (Toenail, Fingernail and Hair Samples) and Drinking Waters of Santa Fe Region, Argentina. Asian J. Appl. Chem. Res. 2018, 1-14. [CrossRef]

77. Phan, H.L.; Tessier, C. Method for Treating Heavy Metals from An Effluent Containing Chelating Agents (EDTA, CDTA, Or Citrate). U.S. Patent Application No. 11/463,439, 2008.

78. Bolto, B.; Gregory, J. Organic polyelectrolytes in water treatment. Water Res. 2007, 41, 2301-2324. [CrossRef]

79. Zazouli, M.A.; Kalankesh, L.R. Removal of precursors and disinfection by-products (DBPs) by membrane filtration from water: A review. J. Environ. Health Sci. Eng. 2017, 15, 25. [CrossRef]

80. Ali, S.I.; Arnold, M.; Liesner, F.; Fesselet, J.F. Characterization of Disinfection By-Products Levels at an Emergency Surface Water Treatment Plant in a Refugee Settlement in Northern Uganda. Water 2019, 11, 647. [CrossRef]

81. Krasner, S.W.; Wright, J.M. The effect of boiling water on disinfection by-product exposure. Water Res. 2005, 39, 855-864. [CrossRef]

82. Carrasco-Turigas, G.; Villanueva, C.M.; Goñi, F.; Rantakokko, P.; Nieuwenhuijsen, M.J. The effect of different boiling and filtering devices on the concentration of disinfection by-products in tap water. J. Environ. Public Health 2013, 2013, 959480. [CrossRef]

83. Liu, J.; Zhang, X.; Li, Y. Effect of boiling on halogenated DBPs and their developmental toxicity in real tap waters. In Recent Advances in Disinfection by-Products; ACS Publishers: Washington, DC, USA, 2015; pp. 45-60. [CrossRef]

84. Kangalawe, R.Y. Climate change impacts on water resource management and community livelihoods in the southern highlands of Tanzania. Clim. Dev. 2017. [CrossRef]

85. Mahoo, H.; Simukanga, L.; Kashaga, R.A.L. Water resources management in Tanzania: Identifying research gaps and needs and recommendations for a research agenda. Tanzania J. Agric. Sci. 2015, 14. Available online: https://www.ajol.info/index.php/tjags/article/download/153336/142927 (accessed on 25 June 2019). 
86. Noel, S. The Economics of Climate Change Tanzania. Water Resources; Stockholm Environment Institute SEI-Africa Centre, Institute of Resource Assessment, University of Dar es Salaam: Dar es Salaam, Tanzania, 2012; p. 32.

87. Ministry of Water. List of Private Companies and Institutions with Valid Groundwater Drilling and Groundwater Exploration Licenses in Tanzania Mainland. 2019. Available online: http://www.maji. go.tz/uploads/publications/en1556795070-kampuni\%20za\%20kuchimba\%20maji\%20final.pdf (accessed on 20 June 2019).

88. Driling and Dam Construction Agency_DDCA: Performance Report 1999-2015. Available online: http://www.ddca.go.tz/storage/app/uploads/public/58e/393/f8b/58e393f8b6394101742489.pdf (accessed on 20 June 2019).

89. Nkonya, L.K. Realizing the human right to water in Tanzania. Hum. Rights Brief 2011, 17, 5.

90. Tanzania National Bureau of Statistics NBS. 2019. Available online: http://worldpopulationreview.com/ countries/tanzania-population/ (accessed on 20 June 2019).

91. Baumann, E.; Ball, P.; Beyene, A. Rationalization of Drilling Operations in Tanzania. Review of the Borehole Drilling Sector in Tanzania. 2005. Available online: 2005https:/sswm.info/sites/default/files/reference_ attachments/BAUMANN\%20et\%20al\%202005\%20Rationalization\%20of\%20Drilling\%20Operations \% 20in\%20Tanzania.pdf (accessed on 27 June 2019).

92. Danert, K.; Carter, R.C.; Adekile, D.; MacDonald, A. Cost-Effective Boreholes in Sub-Saharan Africa. 2009. Available online: http://nora.nerc.ac.uk/id/eprint/9185 (accessed on 28 June 2019).

93. Danert, K.; Armstrong, T.; Adekile, D.; Duffau, B.; Ouedraogo, I.; Kwei, C. Code of Practice for Cost-Effective Boreholes. Rural Water Supply Network. 2010. Available online: https://www.ircwash.org/sites/default/files/ Danert-2010-Code.pdf (accessed on 28 June 2019).

94. Tanzania National Audit Office NAOT. Performance Audit on the Management of Water Supply Projects from Borehole Sources in Tanzania: Report of the Controller and Auditor General of the United Republic of Tanzania. 2019. Available online: http://www.nao.go.tz/?wpfb_dl=296 (accessed on 20 June 2019).

95. National Research Council. Soil and Water Quality: An Agenda for Agriculture; National Academies Press Publisher: Washington, DC, USA, 1993. [CrossRef]

96. Li, H.; Cohen, A.; Li, Z.; Zhang, M. The Impacts of Socioeconomic Development on Rural Drinking Water Safety in China: A Provincial-Level Comparative Analysis. Sustainability 2019, 11, 85. [CrossRef]

97. Koskei, E.C.; Koskei, R.C.; Koske, M.C.; Koech, H.K. Effect of socio-economic factors on access to improved water sources and basic sanitation in Bomet Municipality, Kenya. Res. J. Environ. Earth Sci. 2013, 5, 714-719. [CrossRef]

(C) 2019 by the author. Licensee MDPI, Basel, Switzerland. This article is an open access article distributed under the terms and conditions of the Creative Commons Attribution (CC BY) license (http://creativecommons.org/licenses/by/4.0/). 